\title{
Identifying Factors that Influence the Uptake and Use of Moodle by Academics in three Arts Departments at Roehampton University
}

\author{
Karen Shackleford-Cesare \\ University of Roehampton
}

\begin{abstract}
This paper explores factors influencing both the take-up of Moodle at Roehampton University and the ways it has been used by academics to support learning and teaching. It builds upon the work of others who have sought to explore and explain why the introduction of various technologies in higher education has not transformed teaching practice as expected. This study also seeks to inform policy and practice in the provision of support for academics in their use of learning technologies. A descriptive survey, using a web-based questionnaire and face-to-face, standardised, semi-structured interviews with open-ended questions, was employed to capture relevant data. Of the more important influencing factors identified, respondents' intrinsic technological savoir-faire made them more likely than those without it to use Moodle and, having done so, more of its features and tools. This limited study suggests that male academics are less likely than their female colleagues to change their teaching practice with the introduction of a learning management system (LMS) and that the most significant barrier to use of Moodle is perceived as time. However, the majority of respondents in fact found evidence of Moodle's capacity to save them time to be motivating, as were, significantly, pressure from students to use it and take-up by peers. The most striking de-motivator for Roehampton academics was the prospect of including Moodle usage in the appraisal process. Moderate barriers include a skill or knowledge deficit either on the part of academics or students, along with concerns about the reliability of tools used and students' expectation that the academic will be able to address any technical problems.
\end{abstract}

\section{Overview}

The paper outlines the challenges faced by the support staff responsible for encouraging and supporting academics' use of learning technologies and identifies what could help them in this endeavour. The research topic is presented, together with the 'lines of questioning' and the benefits the researcher hoped to derive from its investigation. The paper then mentions the national drivers that thrust e-learning to centre stage in HE in the last decade and points out that expectations of e-learning have not yet been realised and that e-learning has been expected to 'disrupt' teaching practice. It then discusses alternative views of the transformational impact of learning technologies on teaching. It presents the author's findings in relation to the up-take of Moodle by academics and suggests reasons for these, exploring barriers and motivational aspects. A summary and suggestions for e-learning support policy and further research conclude the paper.

\section{Challenges to be addressed}

Academics are often proactive when requesting access to library resources for research or teaching, but there has been no comparable groundswell of broad-based demand for elearning technologies since their inception (Jenkins et al, 2001; Smith, 2005). Nevertheless, campus-wide learning management systems were established by 2005 in $95 \%$ of universities (including Roehampton University) surveyed across the United Kingdom 
(Browne et al, 2006). Once an LMS was installed in Roehampton, lecturers were strongly urged to use it, though no clear-cut Technology Enhanced Learning (TEL) strategy with associated institutional key performance indicators (KPI) existed to make it mandatory; only vague references to the use of technology to support learning and teaching were included in the University's Teaching, Learning and Assessment Strategy. In this context, the challenges faced by E-Learning Advisors (ELAs) - including the author - who had been primarily employed to facilitate academics' use of the LMS (currently Moodle at Roehampton) included persuading them to:

- use the technology;

- use a variety of tools, especially those that might encourage more student-led learning;

- adapt their pedagogical approaches to include the technologies to enhance learning;

- identify and apply best practice in their use of learning technologies.

Consequently, the research project on which this paper reports was undertaken to investigate factors that influenced both the take-up of Moodle and its use by academics to support learning and teaching. It builds on work by others exploring why, within the context of LMS usage by academics specifically, the introduction of various technologies in higher education has not transformed teaching practice as anticipated (Bush and Mott, 2009,; Blin and Munro, 2008; Zemsky and Massy, 2004). It also serves to help ELAs to address the above challenges by identifying:

- intrinsic and extrinsic factors that motivate academics to use Moodle, or use it more effectively;

- any subsets of the sample population with common attributes, enabling targeted, customised support;

- barriers to Moodle use.

The survey instrument developed for this project gathered demographic data and respondents' thoughts about their use or non-use of computer-based technologies generally, including Moodle. Questions were organised into 5 sections:

- demographic data (age, gender, years spent teaching, teaching qualification and discipline)

- personal approach to the use of computer technologies in general and Moodle in particular;

- the suitability and ease of implementation of certain teaching practices using Moodle;

- obstacles to the use or further use of Moodle;

- factors that stimulate Moodle usage.

\section{The context of the research}

In 2003, the British Government published a white paper on 'The future of higher education' that chronicled changes universities were expected to make to realise the Government's agenda. This included widening access and participation, improving student retention (Department for Education and Skills, 2003; HEFCE, 2001) and increasing choices for 
flexible study underpinned, in part, by e-learning (Department for Education and Skills, 2003; Blin and Munro, 2008). Subsequently, the Higher Education Funding Council for England (HEFCE) was commissioned "to embed e-learning [in $\mathrm{HE}$ ] in a full and sustainable way within the next ten years" (Department for Education and Skills, 2003; HEFCE et al, 2005). Confidence in the prevailing assumption that ICT and e-learning technologies would by default lead to a radical adaptation or 'disruption' of teaching practice was implicit in this drive (Blin and Munro, 2008; Bush and Mott, 2009; Zemsky and Massy, 2004). This conviction and the expectation of a broad-based, grass-roots up-take of e-learning technologies by academics (the two underlying assumptions that formed the backdrop to this study) were not, however, borne out by this author's experience or that of other researchers in the literature explored here: lecturers seem to develop two distinct strategies of behaviourist conditioning that aim to encourage students to attend face-to-face sessions, namely the provision of incomplete lecture slides online and the development of discussions during face-to-face sessions that go beyond the content of online material (Fry and Love, 2011).

Changing notions of effective pedagogy have seen student-centred approaches advocated over traditional tutor-led ones and the rise of the view that the behaviourist paradigm has been overtaken by constructivist principles (Brenton, 2009; Laurilliard, 2010). This development has been paralleled by growth in the use of e-learning technologies, which have in turn brought to the fore more technology-reliant and student-focused learning theories such as connectivism (Bell, 2011) and heutagology (Hase and Kenyon, 2001). Some writers, witnessing this advance, have therefore presumed that learning technology use would support, if not actually bring about, this fundamental shift in teaching practice. It has been assumed that this might come about through the adoption of blended learning approaches, despite the absence of a definitive explanation or definition of what can be reasonably classified as 'blended learning' (Oliver and Trigwell, 2005). So, where some writers may have talked expansively of the transformative potential of e-learning, their viewpoint has lacked specificity. It has therefore been possible to argue either in support of or against their position. However, if, as this researcher asserts, e-learning technologies are seen as having the capacity to influence the 'administrative' or the 'pedagogical' aspect of teaching, a framework wherein these other authors' positions can be upheld or refuted may be established.

\section{The 'administrative' versus the 'pedagogical' uses of learning technologies}

In this particular context, 'teaching administration' can be understood to include those activities and mechanisms by which teachers and/or learners disseminate course information and materials, and evaluate learners' progress and performance through a programme of study. Of all the e-learning technologies, perhaps the most persistent and ubiquitous one adopted is the LMS ${ }^{1}$. It is therefore instructive to identify the support for 'teaching administration' built into LMSs. This would include online tools for facilitating access to course materials, for grading, for processing and presenting grades and tutor feedback, for monitoring student engagement with online content and activities and for gathering and processing student feedback. The term 'pedagogy' in this context can be seen as relating to the ways in which e-learning technologies are implemented to support one or

\footnotetext{
${ }^{1}$ Browne et al (2006, p. 3-4) reported that LMS usage at HE institutions increased to $95 \%$ (of 85 respondents) in 2005 from $81 \%$ (of 75 respondents) in 2001.
} 
more of the learning theories that a teacher applies to his/her practice. The use made of some of a LMS's tools, such as a forum or a discussion board, may thus belie a teacher's constructivist approach to his/her teaching practice. However, a forum or a discussion board can also be utilised in a fashion that reflects a teacher's behaviourist bent. For instance, a forum may be set up to facilitate tutor-led, tutor-to-student and/or student-to-tutor exchanges rather than the social learning model of primarily fostering student-led peer-to-peer communication. Somewhat ironically, Turcan notes that a number of "tools and features that are present in LMSs are very suitable for integration with current educational practices and do not require big changes to the current [ 'traditional'] teaching style and educational practices" (Turcan, 2010). She also cites Weller (2006), who identifies these very characteristics as having contributed to the relative popularity of LMSs.

Figure 1: a representation of blended learning, displaying its component parts from the author's perspective - the weighting of each component may vary

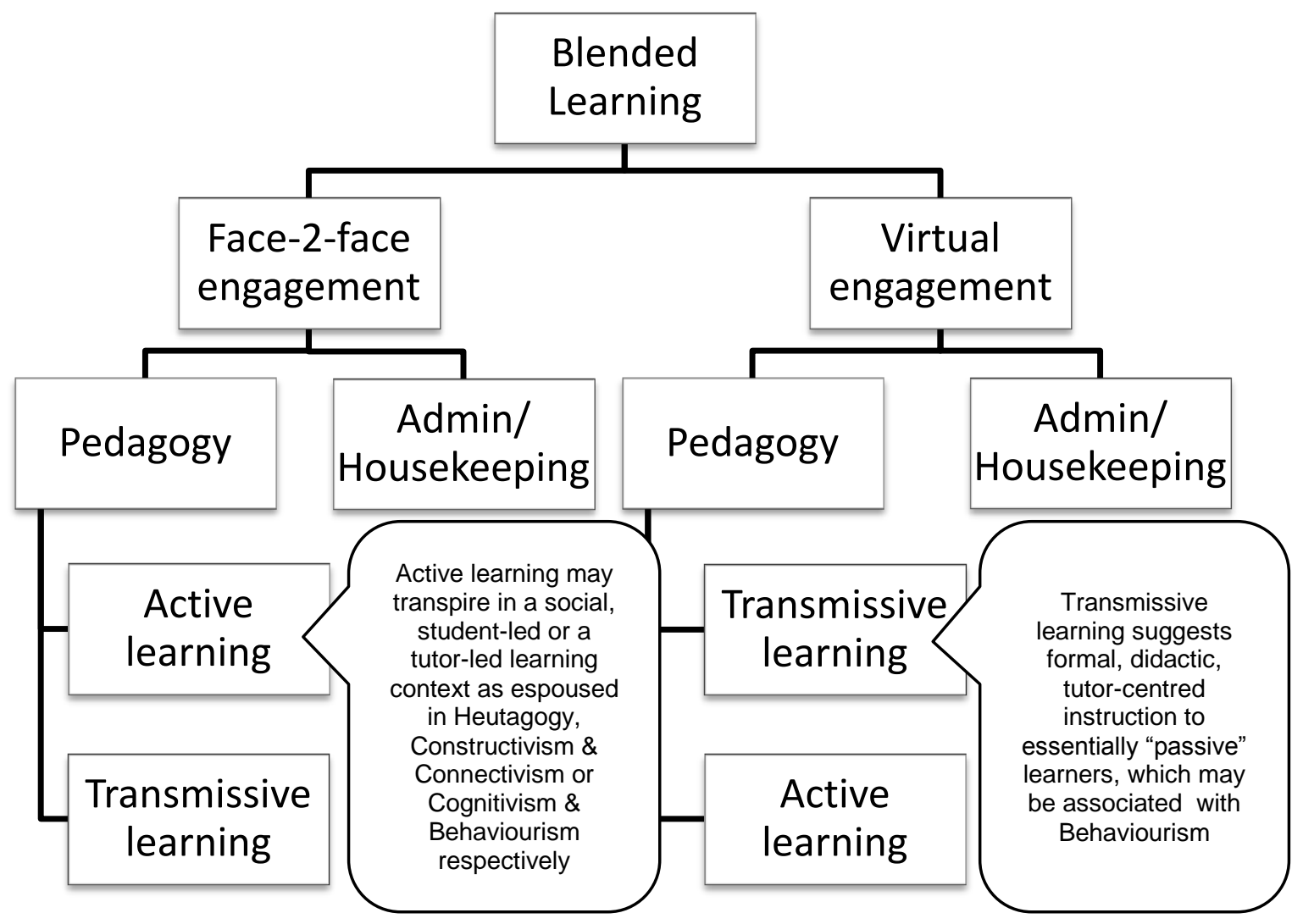

This highlights a difficulty for researchers investigating the transformational promise of elearning: Teachers' use (or non-use) of particular tools (or types thereof) will not alone provide sufficient evidence to categorise the theoretical nature of their personal dominant teaching practice, or to determine whether it is effective. In the context of blended learning course delivery modes, for example, students may have modern humanist, heutagogical or constructivist learning experiences in the more dominant face-to-face component of their course, but the online element may have more in common with a behaviourist approach. Heaton-Shrestha et al (2005) found that many staff participants in their study tended not to use their LMS (Blackboard(C) to encourage collaborative work among students because they preferred 'live' dialogue, seeing it as an opportunity to observe their students. Nevertheless, the literature on LMSs abounds with empirical research identifying the "need to encourage academic staff to shift emphasis away from content dissemination towards facilitating more 
independent and activity-based learning" (Department for Continuing Education, University of Oxford 2010). However, as the above example indicates, such research may not adequately distinguish between teachers who typically adopt a traditional teaching practice in all settings, (including their use of LMSs), and those who only exhibit a traditional approach to teaching in the way they use a LMS.

\section{The application of different theoretical perspectives}

It may not be desirable, necessary or even helpful for teachers to have a more humanist approach in every setting and context. In fact, research in the fields of cognitive psychology and neuroscience in relation to how the mind learns demonstrates the benefits of using a variety of approaches. Daniel Willingham (2002) makes a distinction between "rote" knowledge and what he regards as being far more common, namely, "inflexible knowledge"2, which he sees as "a normal product of learning" and "the unavoidable foundation of expertise [that includes the ability] to solve novel problems by applying existing knowledge to new situations - sometimes known popularly as 'problem-solving' skills." Indeed, such skills are normally a highly-prized product of education. Willingham goes on to explain that knowledge becomes increasingly "flexible" as stores of facts and examples accumulate over time, facilitating an understanding of "the deep structure of a large domain" (a plausible definition for 'expertise'), which in turn is an important goal of education. Willingham argues that it is therefore important to "build students' factual knowledge base... [as] knowing more facts makes many cognitive functions (e.g., comprehension [and] problem-solving) operate more efficiently." Even in a student survey, most respondents agreed that "not every area of study needed, or was compatible with, e-learning, and so to assume it would grant blanket advantages was not accurate" (National Union of Students, 2010). It therefore seems reasonable to conclude that effective and efficient learning may require that the teacher apply of a range of pedagogical or theoretical perspectives in his/her practice.

That certain e-learning technologies such as LMSs have been used effectively to aid teaching administration does suggest that they have brought about significant and positive change to teaching practice, regardless of the teacher's pedagogical and theoretical persuasion. Substantial reduction in teacher use of photocopiers and student requests for hard-copy information has certainly saved time and frustration for all in Higher Education. Perhaps, therefore, the key e-learning issues to be addressed are to determine whether the theoretical basis of teachers' academic practice is in keeping with current evidence of best practice in their circumstances and then to explore how the administrative aspect of elearning can provide a means to support suitable social learning or humanist approaches to teaching, thereby making it easier or more advantageous to introduce, continue or extend these practices where appropriate. Cath Ellis (2011), in her presentation on using Turnitin@'s GradeMark@ tool for effective assessment management, emphasises the need to address academics' workload concerns and to find a way to "take work off them" in order to win them over to a new product or way of working. In addition, she demonstrates how an e-learning tool can deliver far-reaching benefits for both students and teachers in the arena of "teaching administration". One such benefit is GradeMark's facility for easily aggregating and charting marking concerns or performance against specific rubrics that can be presented in class for

\footnotetext{
2 "Inflexible knowledge" is probably best explained by describing "flexible knowledge": "knowledge is flexible when it can be accessed out of the context in which it was learned and applied in new contexts" (Willingham 2002).
} 
greater effect and class discussion. Through the use of such tools, a lecturer can gain additional benefits from swapping manual for online marking.

This study did not set out to explore fully the impact of e-learning at Roehampton, nor, indeed, how it affected the 'administrative' and 'pedagogical' aspects of teaching, as previously described by this researcher. It did not, for example, directly investigate the theoretical basis of the sample population's face-to-face teaching practice or the influence of this in its application of learning technologies such as the LMS. However, it does attempt to gauge what kinds of practice, typically associated with a constructivist ethos, academics struggle to implement using LMS tools.

\section{The findings of similar studies on which this study builds}

Janet Hanson (2003) investigated factors "affecting the adoption of online learning by lecturers at Bournemouth University and their motivation to change their teaching methods." This study, in surveying Roehampton's academics in 2011, seeks (specifically in relation to support) to corroborate her findings. Hanson's study identified three key motivators: "the need to see the University's overall strategy for online learning, having the time and resources to engage with it and feeling supported in their attempts to use it." The support that appealed to her respondents combined technical expertise with the "ability to design curriculum support materials" and provided guidance regarding the best ways to use online learning to achieve set goals (Hanson, 2003). In the decade since Hanson conducted her research, learning technologies have become more wide-spread, accessible and userfriendly (Schneckenberg et al, 2010), and more academics may now, therefore, be assumed to use them. Thus, the impact of various demographic variables on usage, together with the training and support required by some academics, may also have changed. The author's study also parallels Turcan's by looking at the impact of age, gender, years spent in teaching and the academic's department or discipline, as well as whether or not s/he holds a teaching qualification (TQ) in LMS usage. Turcan (2010) also cites an article by Skelly (2009), who refers to various age groups in terms of their being 'tech savvy'. Although Skelly did not define this phrase, this researcher devised a rudimentary measure of technical savoir-faire (discussed in the next section), possession of which capability appeared to be an intrinsic motivator for the uptake and use of Moodle.

This researcher, however, also aimed to explore at Roehampton the nature and extent of the disconnect Hanson identified between academics' knowing how to use the technology and their being able to incorporate it into a sound pedagogical framework to promote learning (Hanson 2003), as information about this could inform Roehampton's e-learning training and support schemes. To this end, the survey methods used were informed by Ellis et al (2006), who explored the meanings lecturers attach to the phrase 'blended learning' in the context of both learning and teaching and, in consequence, their radically different approaches to course delivery. This work also highlights the need properly to integrate technology into teaching and learning processes.

Heaton-Shrestha et al (2005) researched "the specific ways in which practice has been transformed by the LMS" and how existing practice has been shaped by its use. Like this researcher, they also explored factors that have encouraged or discouraged LMS use. They 
identified areas in which Kingston University's LMS (Blackboard()) had had 'little', 'modest' or 'significant' impact on teachers' practice.

Within its modest compass, this research explored elements that motivate Roehampton's academics to use the LMS and those which discourage them from exploiting it. It considers some possible intrinsic and extrinsic influences and, like Turcan, explores the intrinsic factor of being "tech-savvy". In line with Heaton-Shrestha et al and Hanson, it looks into extrinsic factors such as the availability of time and other resources as well as the nature of needed support. In addition, it (like Turcan's) considers the relevance of various demographic factors on the uptake of technologies like the LMS.

\section{Methodology}

This research was broadly quantitative with qualitative aspects. It employed one type of Minger's multi-method design that he labelled "sequential", in which "methods were employed in sequence, with results from one feeding into the later one" (Minger, 2001). Although in this study the data from one research method was not combined for statistical analysis with that of the other, data from the first method was used to devise questions for the second. Given the descriptive nature of the study, the most appropriate and primary data collection tool was an anonymous web-based survey questionnaire (Glatthorn, 1998) that comprised mainly closed, scaled questions with some short-answer open-ended questions.

Each set of related closed questions was followed by an open question inviting respondents to comment on issues they inspired. Open questions therefore captured data that closed questions failed to elicit. Respondents were asked to participate in a 1-to-1 standardised interview or focus group. Interview questions were formulated from responses to the online survey's open-ended questions. The survey population comprised the non-probability sample of all 74 academics employed in three Arts departments and the response rate was $59.5 \%$.

Despite the relatively high response rate, the actual number of respondents was insufficient to apply certain statistical tests that require larger data sets (Denscombe, 2007). To give credence to the simple statistical tests that would be viable, given the relatively small data set, it was necessary to narrow the range of responses to a number of questions. For example, in question 1, there were six age groups from twenties to seventies. However, as only one Figure 2: Distribution of Respondent's Ages respondent was in his/her twenties and none was over sixty-nine, for the purposes of sound statistical analysis, the data was divided into two subsets, those '20 to 49' (20 respondents) and those '50 to 69' years old (24 respondents), (see Figure 2). 
The methodology was problematic in that the sample size, coupled with the subjective nature of the data captured, doubtless affected the conclusions' validity; in addition, the need to simplify the response or Likert scales for the purpose of statistical analysis could arguably have reduced the sensitivity of the findings.

There were practical difficulties with the web-based questionnaire: Some academics may not have participated because it was online, potentially skewing the results; the online survey tool prevented respondents from returning to previous screens, which may partly explain missing responses; some questions allowed multiple options to be selected, which could have caused a respondent to provide conflicting data.

\section{Findings}

Charts were generated in Excel, with data captured via the online instrument. SPSS was used to identify statistically-significant associations between pairs of variables by applying Fisher's Exact Test (FET).

\section{Interpreting the Charts in Figures 2-9}

The title of each chart comprises both the number of the online question and the question itself. The numbered statements or options found along one axis are the options that respondents were asked to select from. The numbers or percentages on the other axis represent the number, or the proportion, of respondents who selected each option.

\section{Personal approach to the use of computer technologies in general and of Moodle in particular - the 'tech-savvy' variable.}

The researcher hypothesised that those respondents more au fait with a range of technologies that can aid learning would be more inclined to engage with Moodle than those who weren't, especially if use of these technologies was optional. Respondents were therefore described as being 'tech-savvy' if they used over fifteen of thirty non-essential technologies. (See Figures 3 and 4 for a breakdown of the technologies listed in online questions 6 and 8 and the contexts in which they were used.) Fifteen items was designated as the break point because this number allowed for a combination of more common technologies and a few less-familiar ones. The technologies in question were selected either because personal ownership/use was found to be quite commonplace or the elearning team or other university support teams encouraged their use and/or made them available to staff and/or students for teaching and learning purposes. Equipment furnished by the university included the hardware items listed in question 6 and shown in Figure 3, excluding only $6 \mathrm{a}, \mathrm{b}$ and $\mathrm{k}$, which were found from informal checks with Library staff to be relatively common household items. The software/online items listed in question 8 and shown in Figure 4 were selected because the e-learning team, the Library or IT Services supported their use. In fact, the researcher's hypothesis was supported by the positive correlation found between the 'tech-savvy' variable and respondents' self-assessment of their willingness to engage with technology as expressed by agreement with statements $10 \mathrm{a}$, $b$ and $d$ in Figure 5. 
Table 1: General computer technology use versus moodle usage or support

\begin{tabular}{|l|c|}
\multicolumn{1}{|c|}{ General Technology Usage relative to Moodle Usage/Support } & $\begin{array}{c}\text { No. of } \\
\text { Respondents }\end{array}$ \\
\hline Uses over 15 of 30 technologies listed and is a relatively keen Moodle user and supporter & $16(36 \%)$ \\
\hline Uses over 15 technologies but is not a keen user or supporter of Moodle & $3(1 \%)$ \\
\hline Uses less than 15 technologies but is a relatively keen user and supporter of Moodle & $11(25 \%)$ \\
\hline Uses less than 15 technologies and is not a keen user or supporter of Moodle & $14(32 \%)$ \\
\hline & TOTAL \\
\hline
\end{tabular}

Surprisingly, a relatively high proportion of supposedly non tech-savvy respondents were keen 'Moodlers'. This could attest to the relative user-friendliness of Moodle vis-à-vis Blackboard/WebCT, as highlighted by Turcan (2010) and indicated by open-ended question responses, such as:

Q: 11.3: "I find Moodle much easier to use than studyzone [Blackboard/WebCT] which I did find daunting."

Q: 11.4: “...I have to say I found WebCT very difficult to use.”

Given the researcher's hypothesis, the fact that three respondents were 'tech-savvy' but resistant to Moodle was an anomaly: examination of the data did not reveal any reason for this. However, each of these three respondents did share one or two of the views held by 'non tech-savvy', Moodle-averse respondents; they included a lack of skill and confidence in the use of Moodle, a lack of knowledge about what it can offer their discipline and doubts about the suitability of Moodle in the context of their teaching practice. Even so, despite issues concerning the extent to which academics' teaching practices have been radically "disrupted" (Blin and Munro, 2008), their overall willingness to use Moodle was encapsulated by one response to an open question:

20.4 "This time last year I was sceptical of Moodle and of online marking. I am now insistent on both!" 


\section{Which digital hardware technology do you use personally and/or for research and/or for teaching?}

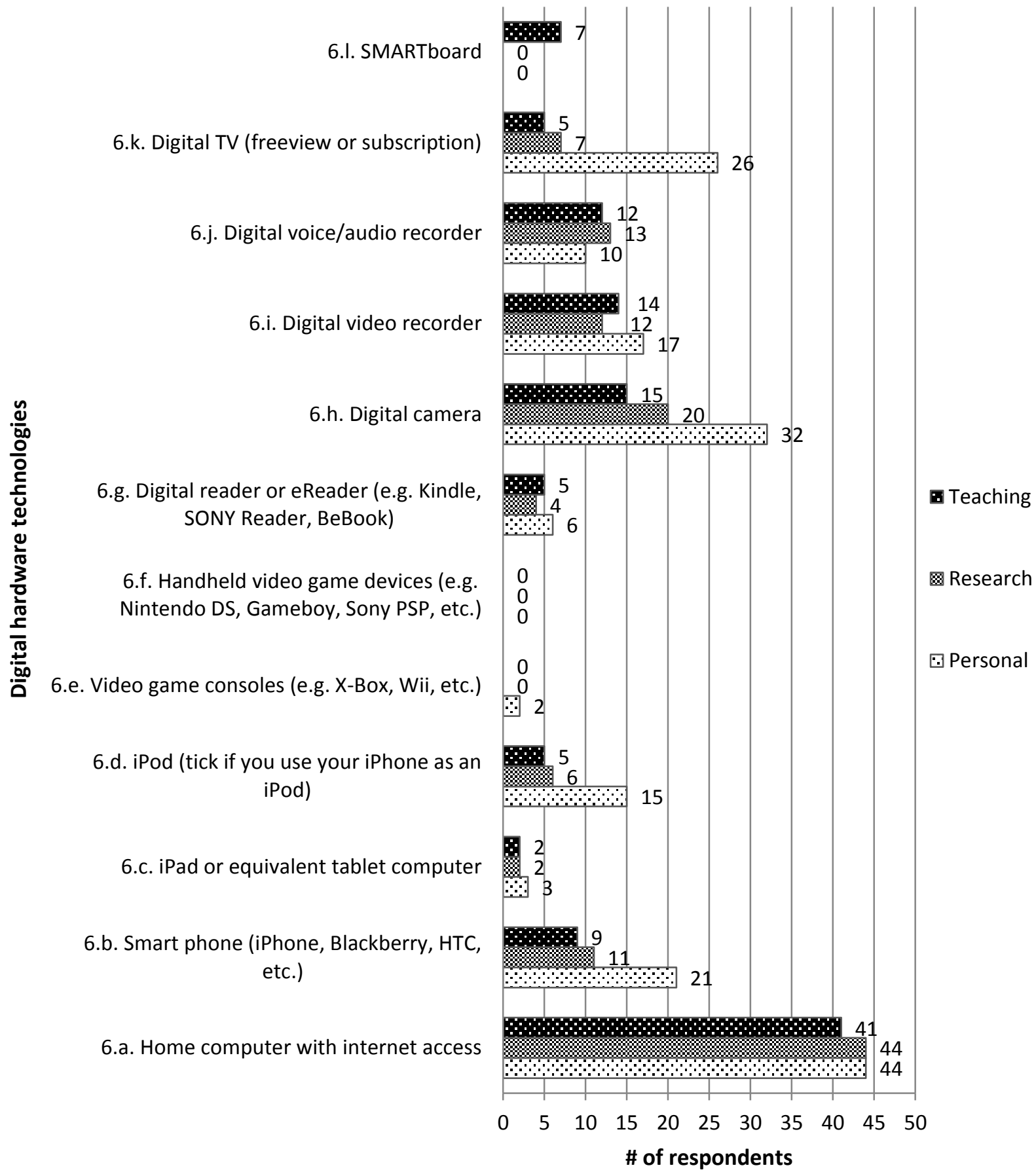

Figure 3: Q-6. Digital hardware technology used by respondents for personal use \&/ for research \&/ for teaching 


\title{
8. Which online technologies do you use personally and/or for research and/or for teaching?
}

\author{
8.r. e-Portfolio (e.g. Mahara, PebblePad) \\ 8.q. iTunes or BBC iPlayer \\ 8.p. Collaboration tools (e.g. Google Documents, \\ DropBox)
}

8.o. Podcasting (e.g. creating and then distributing audio files on Podomatic)

8.n. Online photo sharing (e.g. photos on Flickr, Picasa)

8.m. Online audio/podcasting (listening to...)

8.I. RSS feed readers (e.g. Netvibes, PageFlakes, Google Reader)

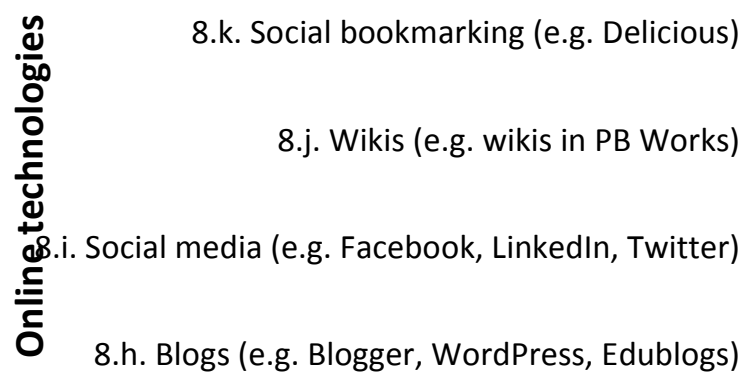

8.g. Virtual learning environments (e.g. StudyZone, StudyZone:moodle)

8.f. Electronic texts, (e.g. eBooks, eJournals, digitised text)

8.e. Instant messaging or chat services

8.d. Skype or other audio/video over IP (e.g. Eluminate, Flashmeeting, BlueButton, DimDim,...

8.c. Online video (e.g. YouTube, Vimeo, TeacherTube, Box of Broadcasts (BoB))
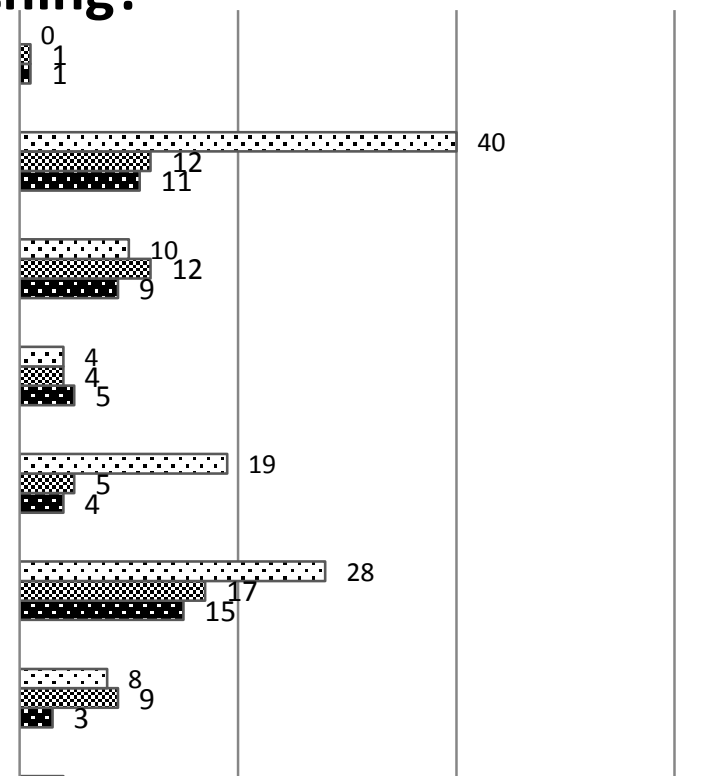

Personal
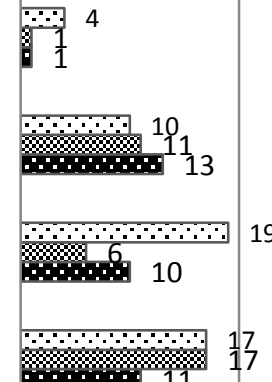

Research

Teaching

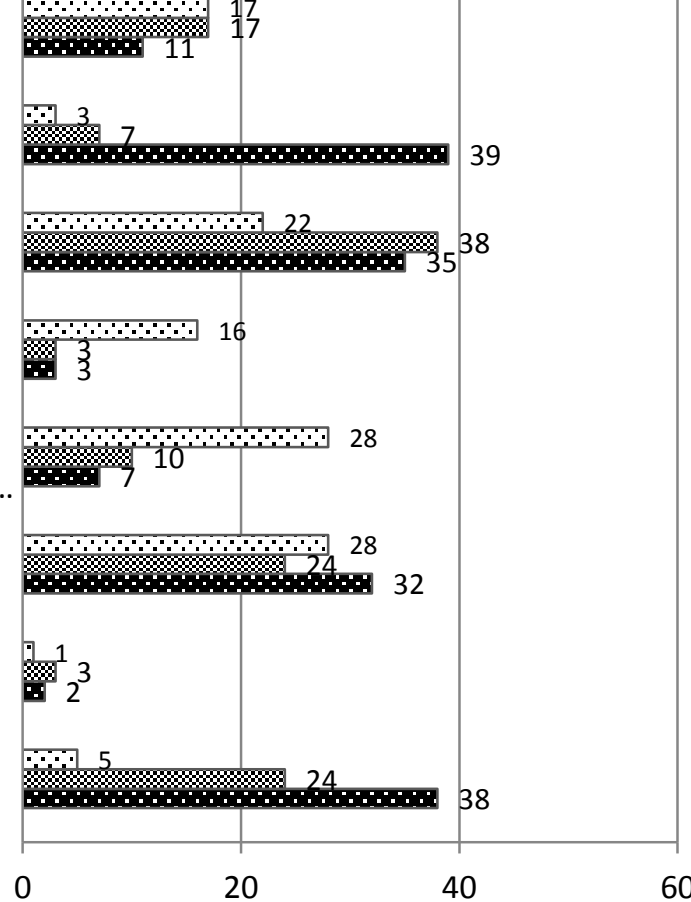

60

\# of respondents using technology in a given sphere of activity

Figure 4: Q-8. Online technologies used by respondents for personal use \&/ for research \&/ for teaching 


\section{Approach to computer technology and Moodle use}

10.i. I believe using moodle can enhance learning in one or more of my modules.

10.h. I think moodle is conducive to teaching my subject and/or how I teach some of my modules.

10.g. I've found learning the many different of tools and features in moodle to be daunting.

10.f. The way I teach one or more of my modules has changed significantly as a consequence of using moodle or StudyZone.

10.e. I am using moodle to support my students' learning in most of my modules.

10.d. I am very keen to use features and/or tools in moodle that I haven't used before.

10.c. I believe the time and effort I need to invest to use moodle is time well spent.

10.b. I DON'T tend to stick with what I know regarding my use of computer based technologies and I'M inclinED to experiment.

10.a. I am eager to learn and experiment with unfamiliar, but potentially useful software applications.

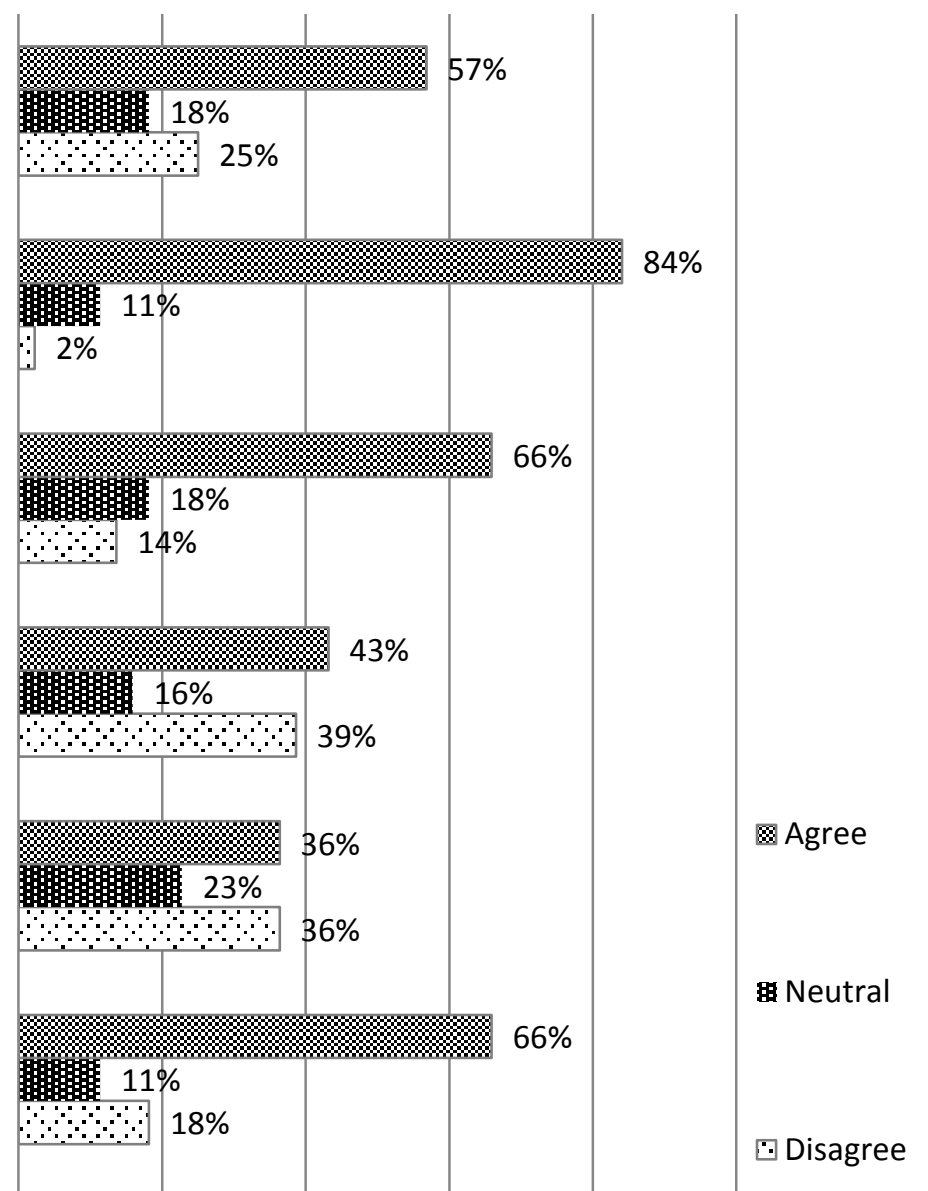

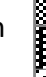

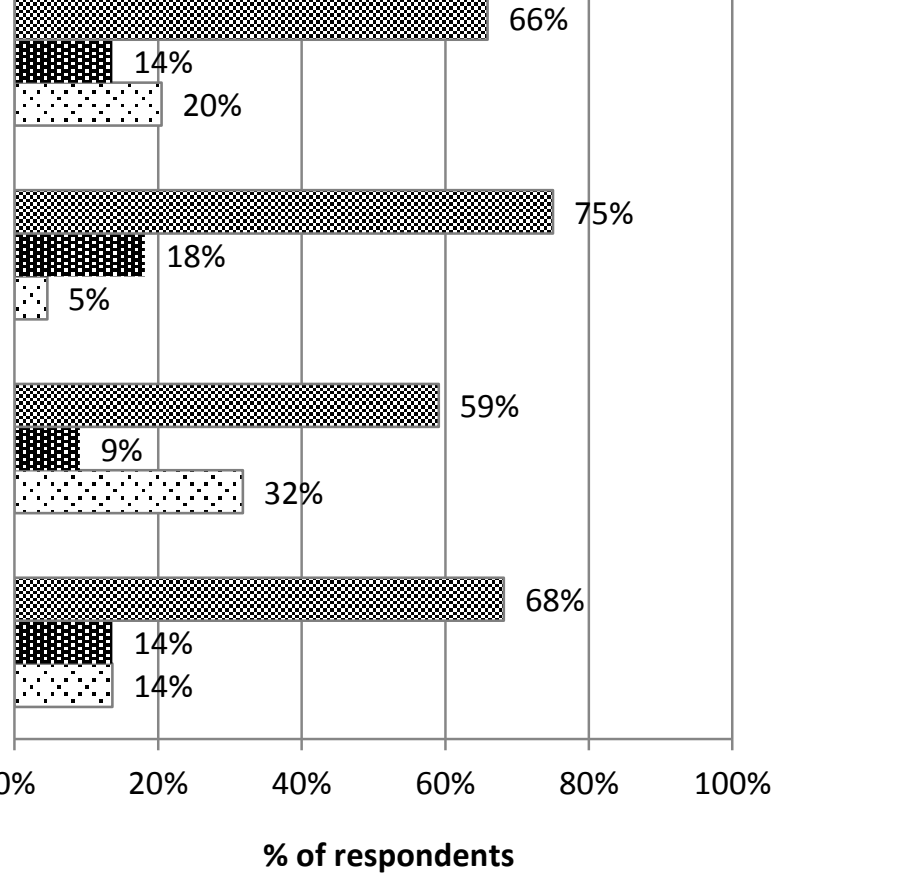

Figure 5: Q-10. Respondents' approach to computer technology and Moodle use 
Identifying characteristics by which academics may be grouped:

\section{Analysis of demographic data and users' "Approach to Computer Technology and Moodle Use"}

Unfortunately, the study did not reveal any simple demographic or small set of attributes that would enable the researcher to classify academics into groups with common training needs. Statistical analysis was carried out in search of an association between each of the demographic variables and technical savoir-faire along with five other variables (see Figure 5 , questions $10 \mathrm{a}, \mathrm{b}, \mathrm{f}, \mathrm{i}$ and $\mathrm{j}$ ) that collectively relate to the respondents' general interest in exploring what technology has to offer and their confidence in using Moodle, as well as the extent to which it has affected their teaching practice.

Age did not appear to be a significant factor in academics' uptake of technology generally. However, the picture changes in relation to the 'transformational' impact of LMS use, in that $50 \%$ of those $50+$ years old felt their teaching practice had changed significantly, as opposed to only $27 \%$ of under-50s who held that view. Also, those under 50 tended to be more confident in their ability to use Moodle.

Gender was not a significant factor in relation to these variables, but the impression given within the context of this limited data set is that male academic Moodle users are least likely to change their teaching practice.

Neither the 'years an academic has spent teaching' (YST) nor having a 'teaching qualification' (TQ) was a significant factor in relation to these variables. The same is true for an academic's department. There is nevertheless an association between being 'tech-savvy' and teaching a specific discipline. 64\% (7/11) of Dance respondents and 67\% (8/12) of Drama respondents were 'tech-savvy' as defined in this study but only $19 \%$ (4/21) of English and Creative Writing respondents were classed as 'tech-savvy'.

\section{The suitability and ease of implementation of certain teaching practices using Moodle}

An online questionnaire design consideration was that it should not be perceived as a mechanism for 'checking up' on what academics were doing, but rather as a means of exploring their attitudes, interests, support needs and motivations regarding learning technologies. So, online question 12 ("With Moodle, how easy or unproblematic (in terms of your time, or ability, or access to resources) is it to" do any of the following, labelled 12a-m) did not set out to determine whether respondents were using a particular tool, or using it in a certain way, or using it for a particular purpose. (See Figure 6 for the responses to online question 12.) Instead, it attempted to gauge academics' awareness about the role a given technology can play in supporting learning as well as their confidence in their ability to incorporate it into their teaching. This 'ability' could signify having the necessary technical know-how to use the tool(s) and/or having the "pedagogical" vision to see how its use could enhance learning within the specific context of their module(s). The researcher therefore assumed that respondents who thought it was either 'unnecessary' or 'undesirable' to use certain tools for a suggested purpose lacked one or both 'abilities', and felt that their learning objectives could be achieved without them. Respondents who reported finding a given suggestion 'easy' to implement may not actually have been doing it, but the researcher 


\section{Articles}

assumed that they felt confident in their 'ability' to do so both technically and pedagogically. On the other hand, those who said they found it problematic or challenging were assumed to lack confidence in their technical and/or pedagogical ability.

Unsurprisingly, on average, $70 \%$ of respondents found tasks (like 12a, b and $f$ in Figure 6 ) related to housekeeping and content storage 'easy', whilst, on average, only $20 \%$ of respondents found tasks that support active learning (e.g. 12d, i, j, k and $\mathrm{m}$ ) 'easy' to implement.

Additional support for the interpretation of Figure 6 can be found in the findings compiled in Figure 7. This chart displays respondents' awareness of what the various tools and features in Moodle can facilitate. Again, the majority of respondents were 'aware' of Moodle's 'document repository' and 'housekeeping' facilities, as well as facilities for assessment submission and feedback. A larger proportion of respondents reported being only 'vaguely aware' of tools that can facilitate more social learning activities and polling. In addition, equal proportions of respondents said they were 'vaguely aware' (39\%) and 'unaware' (39\%) of facilities in Moodle that facilitate the co-creation of content in Moodle. 


\section{With Moodle how easy or unproblematic (in terms of your time, or ability, or access to resources) is it to:}

12.m. encourage reflective learning and peer review through use of any of these: forums, blogs, wikis and the Mahara e-portfolio tool.

\section{I. encourage active engagement with} material by posing related questions.

12.k. use social media tools (e.g. Flickr, YouTube, Facebook, Delicious, PB Works, Twitter, etc.) to compliment what you do in moodle.

12.j. encourage students to participate in online activities with one another.

12.i. participate in online activities with my students.

12.h. keep content on moodle module sites fresh and up-to-date.

12.g. use built-in Reports to monitor student use of moodle.

12.f. let your students know how you expect them to use moodle and what they can expect from you with regards to moodle usage.

12.e. actually use moodle in the classroom and refer to it during classes.

12.d. evaluate teaching by gathering student feedback.

12.c. assess learning through formative assessment online.

12.b. provide additional reading or resources and set expectations for their use.

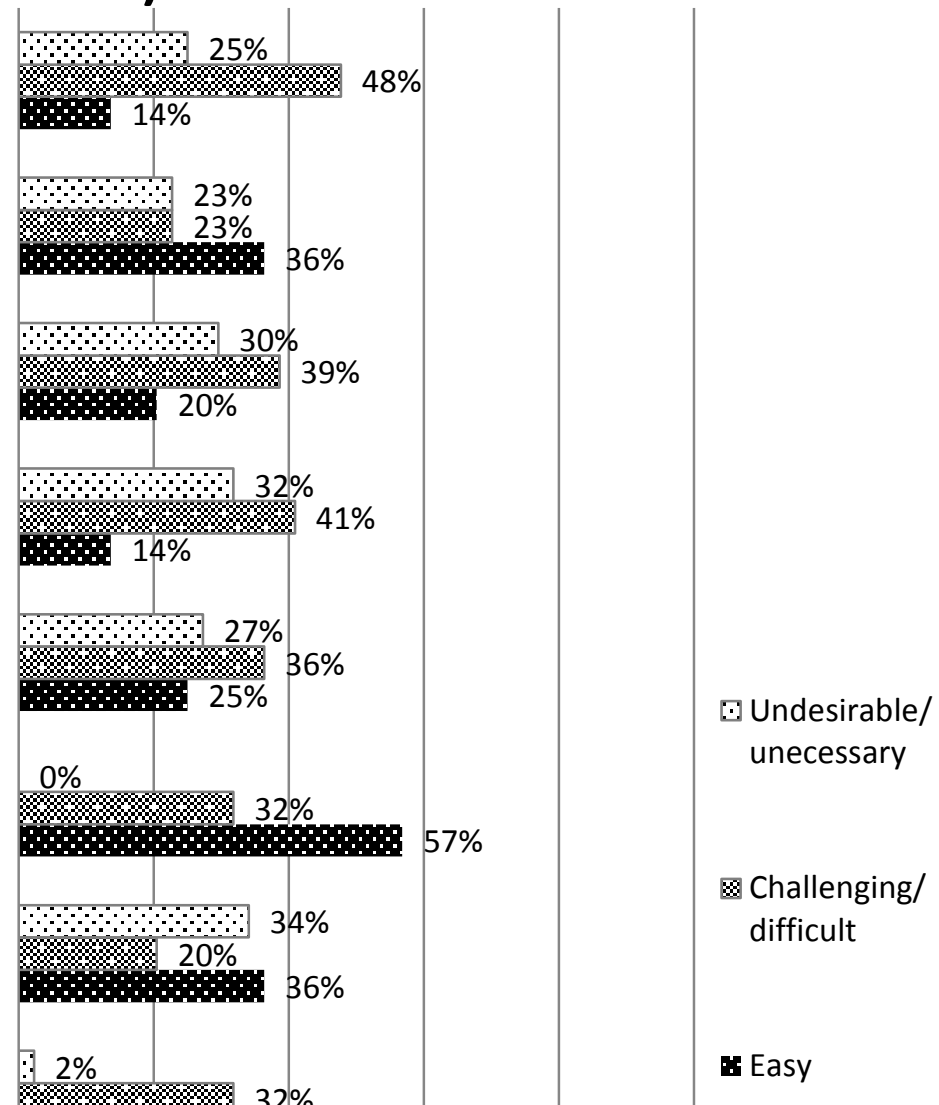

12.a. give your students' access to class content before or after the class.

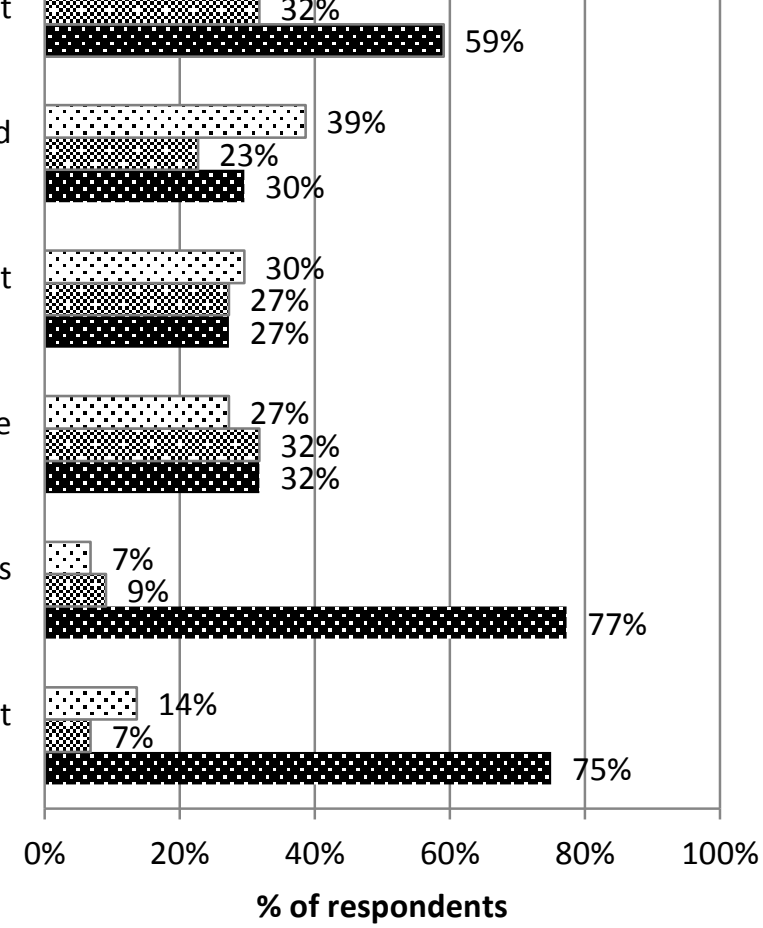

Figure 6: Q-12. With Moodle how unproblematic (in terms of one's time, or ability, or access to resources) is it to do the above 


\section{Articles}

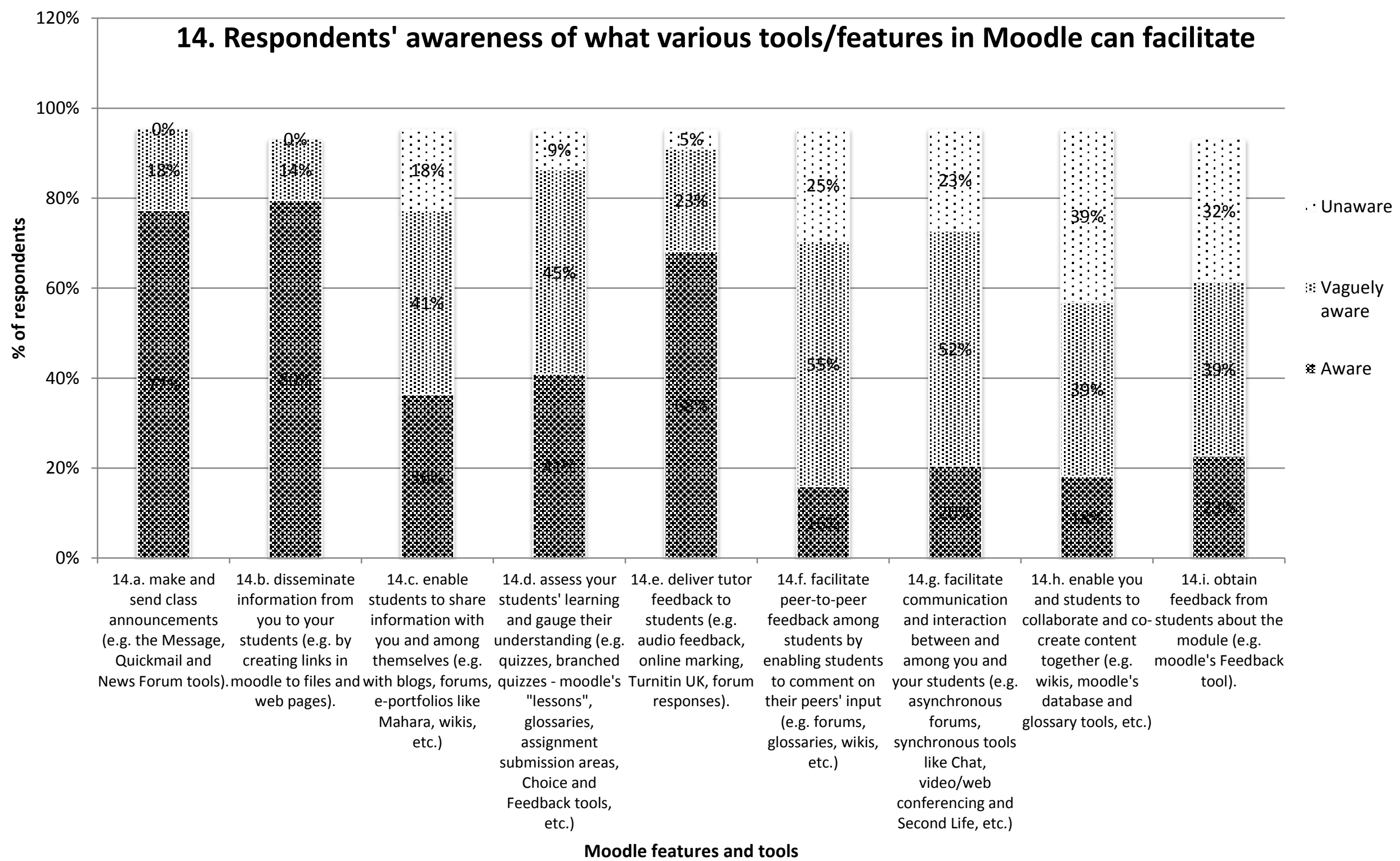

Figure 7: Q-14. Respondents awareness of what various tools and features in Moodle can facilitate 


\section{Barriers and motivators to Moodle usage}

Figures 8 and 9 render the responses to online questions 16 (on 'barriers') and 18 (on 'motivators') respectively, and the researcher used these charts to derive two lists, one of potential 'barriers' found to deter Moodle use and the other of possible 'motivators' that encourage it. These lists were derived by selecting the response option that the majority of respondents selected in relation to each 'barrier' stated in questions 16a-I and to each 'motivator' posed in questions 18a-i. Table 2 highlights the factors that the majority of respondents thought were a 'significant barrier/motivator' or a 'moderate barrier/motivator' or an 'insignificant barrier/motivator'. The factor most respondents $(61 \%)$ thought was a 'significant barrier' to Moodle use was lack of time, whilst the majority of respondents (75\%) thought the exclusion of Moodle use from the appraisal process was an 'insignificant barrier'.

Table 2: Summary of motivator \& demotivators to VLE use adapted

\begin{tabular}{|c|c|c|c|}
\hline Level & Barriers & Level & Motivators \\
\hline $\begin{array}{l}\text { Significant } \\
\text { barrier }\end{array}$ & - Lack of time* & $\begin{array}{l}\text { Significant } \\
\text { motivator }\end{array}$ & $\begin{array}{ll}\text { - } & \text { Time saving capacity* } \\
\text { - } & \text { Student pressure* } \\
\text { - } & \text { Its use by peers* } \\
\text { - } & \text { Better learning outcomes } \\
\text { - } & \text { Positive feedback } \\
\text { - } & \text { Customised subject- } \\
& \text { centred support } \\
\text { - } & \text { Better functionality }\end{array}$ \\
\hline $\begin{array}{l}\text { Moderate } \\
\text { barrier }\end{array}$ & $\begin{array}{l}\text { - Skills/knowledge shortfall } \\
\circ \quad \text { Staff } \\
\circ \quad \text { Students } \\
\text { - Unreliability of tools } \\
\text { - Ascribed unwarranted } \\
\text { 'fix-it' role by students }\end{array}$ & $\begin{array}{l}\text { Moderate } \\
\text { motivator }\end{array}$ & $\begin{array}{l}\text { - Inclusion in the appraisal } \\
\text { process }\end{array}$ \\
\hline $\begin{array}{l}\text { Insignificant } \\
\text { barrier }\end{array}$ & $\begin{array}{ll}\text { - } & \text { Lack of suitable tools } \\
\text { - } & \text { Lack of autonomy } \\
\text { - } & \text { Unsuitable for subject } \\
\text { - } & \text { Training deficit } \\
\text { - } & \text { Exclusion from appraisal } \\
& \text { process } \\
\end{array}$ & $\begin{array}{l}\text { Insignificant } \\
\text { motivator }\end{array}$ & $\begin{array}{l}\text { - Inclusion in the appraisal } \\
\text { process }\end{array}$ \\
\hline
\end{tabular}

${ }^{*}$ Factors in common with those identified by Heaton-Shrestha et al.

In the open-ended question responses, the following comments echoed these findings and introduce a concern not included in the closed questions regarding substituting teachers with technology:

17.1 "I would gladly spend hours researching how to use Moodle and implementing the use of its many tools if I wasn't having to juggle this task alongside 100s of other teaching /research /income generation tasks whose deadlines all tend to come at once. I find I use the basic and most obvious tools as I don't have time to test its capabilities."

17.2. "There has not been adequate time to really develop my familiarity on Moodle outside of basic use." 
17.5. "...I've worked in two situations where use of online technologies was used to get rid of a whole swathe of teaching staff. Thus whilst I am enthusiastic about Moodle, I am also slightly fearful that it will be used in this way in my current employment as a cost-cutting device, or, alternatively, as a kind of shibboleth, where, if staff can't use it, it's a black mark against them."

19.2. "I'd be very annoyed (and unmotivated) if Moodle used was made an appraisal objective without my requesting that it be so."

19.4. "re [18]i. It's more likely to switch people off and increase the climate of fear if this became a part of appraisal."

19.6. "Why would I want Moodle usage to be a priority in the context of my appraisal objectives if, as this survey shows, I can't and don't use it, or seem to have the time to learn to use it?" 


\section{6. "What are the most significant barriers to using Moodle, or using more of its tools and features?"}

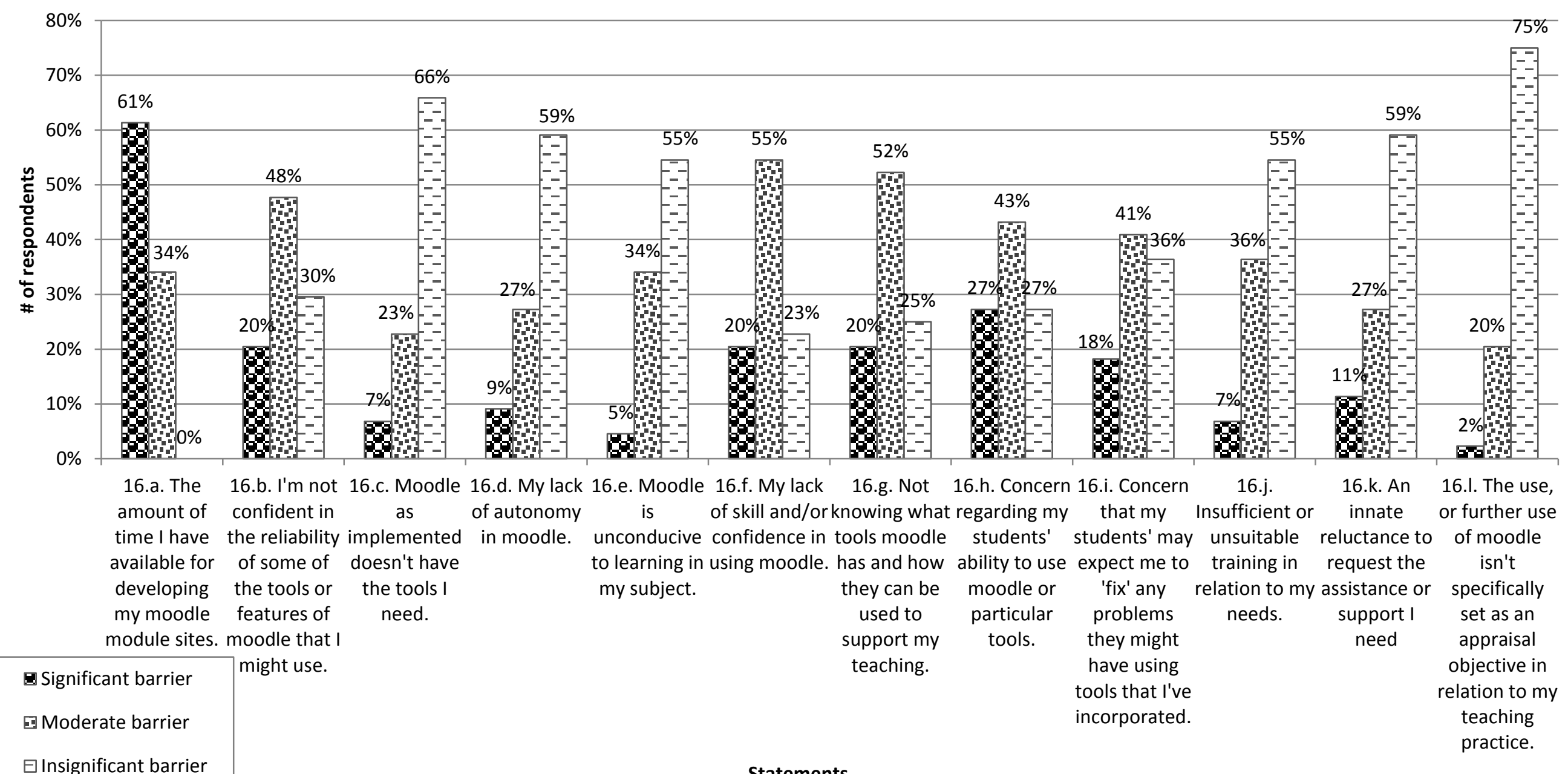

Figure 8: Q-16. Possible Barriers to using Moodle 


\section{Articles}

18. "What would motivate you to use Moodle, or use it more?"

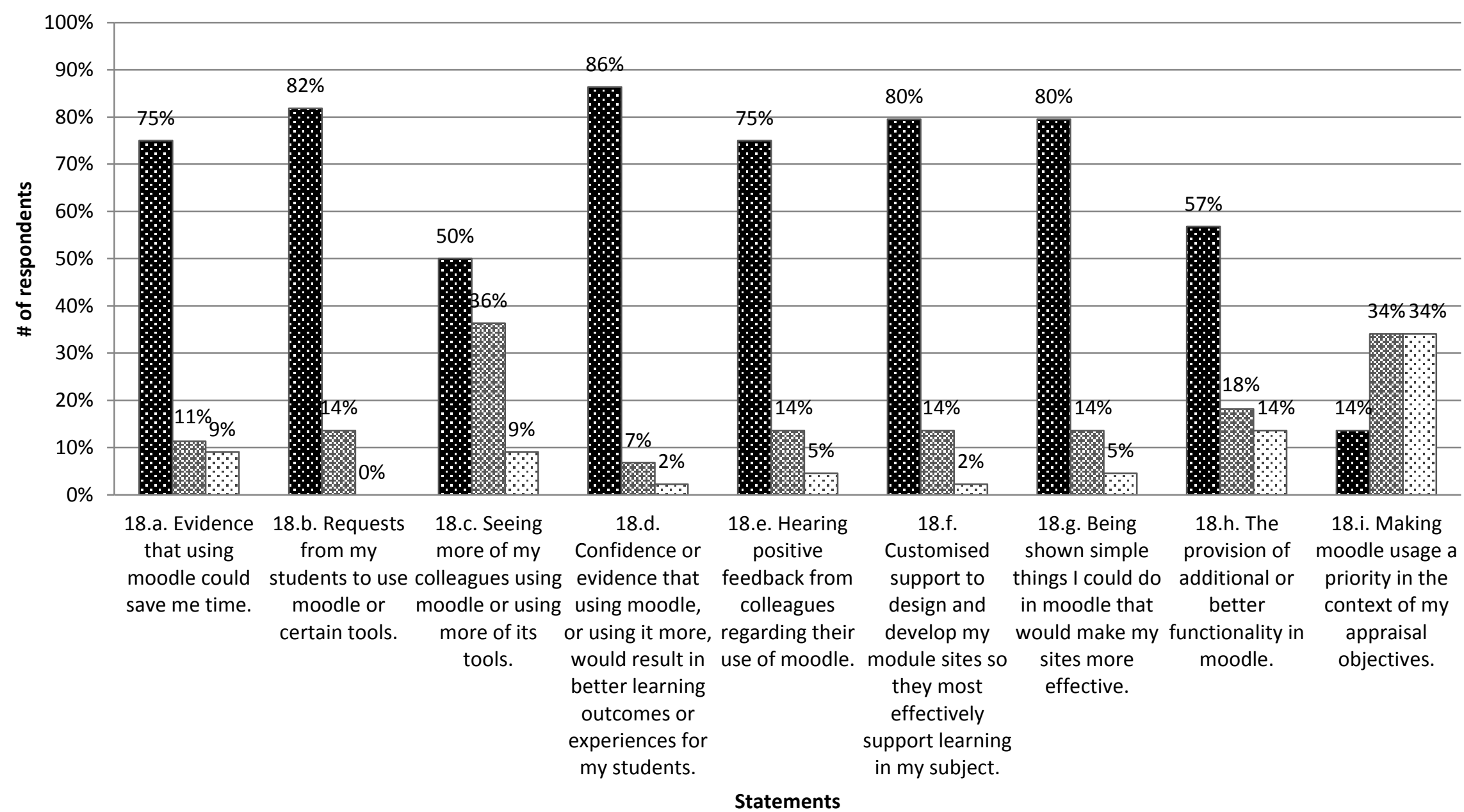

a Significant motivator

Moderate motivator

QInsignificant motivator

Figure 9: Q-18. Possible motivators for Moodle use 


\section{Conclusion}

The more important factors identified influencing the take-up and use of Moodle included academics' intrinsic technological savoir-faire, where those with this characteristic were more likely to use Moodle and more of its tools. Nevertheless, even among those who were not classified as 'tech-savvy' within the context of this study, almost half were overwhelmingly in favour of Moodle and expressed confidence in its ability to support and enhance student learning in one or more of their modules. Other significant extrinsic motivators identified were student pressure to use Moodle and its use by peers.

The things most respondents found 'easy' to do were to use Moodle as a document repository and for general class housekeeping. Most respondents found it challenging or difficult to facilitate online reflection, peer-to-peer learning, student-led activities and formative assessment. In addition, the majority of respondents thought it was unnecessary to take Moodle into the classroom and to conduct student evaluations. Findings such as these support Heaton-Shrestha et als observation that "staff tend to simply model traditional teaching practices onto an e-delivery mode" (HeatonShrestha et al, 2005). The impression given in this limited study is that male academics are even less likely than women to change their teaching practice with the introduction of a LMS.

The most significant barrier to Moodle use was seen as time. Most respondents were motivated by evidence that Moodle could save time. This motivator, along with student and peer pressure, was also identified in research undertaken by Heaton-Shrestha et al (2005). Turcan (2010 expressed the view: "Seeing what motivates faculty is important because it provides valuable information to [those] who decide what [LMS] to use and what resources to allocate." (Turcan, 2010:120) also found that time saving and meeting students' needs were prime motivators (2010:133).

The most significant de-motivator was the possible inclusion of Moodle usage in the appraisal process. The fact that the University did not have a fully-fledged TEL strategy underpinning institutional KPIs may have been a factor behind this. Moderate barriers include a skill/knowledge deficit on either the academics' or their students' part, along with concerns about tool reliability and students' expectation that academics can fix technical problems.

\section{Suggestions for further research and e-learning support policy}

Despite limits on the statistical significance of these findings, going forward, they support practical interventions and avenues for further research, including:

- The importance of an over-arching University TEL strategy that clarifies institutional expectations on embedding learning technologies into the wider learning, teaching, assessment and quality strategy and practice.

- The acquisition of learning technologies highly rated for ease of use and potential for saving time (given that even non 'tech-savvy' academics overwhelmingly favoured Moodle and felt it supported and enhanced student learning); furthermore, as willingness-to-use is greater when a technology is projected to have long 'shelf-life', this should be an important consideration.

- Because student pressure was found to be a motivating factor, Moodle inductions should introduce un-used tools, which students can ask their tutors to use. Similarly, organising staff 
forums and establishing communities of practice where academics share their Moodle experience can boost usage.

- Although further investigation might reveal why academics may refrain from even using familiar technologies in their teaching, it is prudent to bolster efforts to promote internal services that provide and/or support the use of learning technologies on campus, as this could increase academics' willingness to try something new with learning technologies.

- Further research on the impact of teaching qualifications on academics' use of learning technologies is needed, which could also pinpoint the skills required to make activities they find 'difficult', much easier.

- Most respondents found it challenging to facilitate online reflection, peer-to-peer learning, student-led activities and formative assessment. It would be instructive to determine if these forms of active learning are taking place offline and face-to-face and, if so, whether there are any advantages from either replacing or supplementing them with online versions. If so, the findings from this study and comments by respondents/participants highlight the need to offer training and support that imparts both technical know-how and strategies for tackling pedagogical concerns specific to the discipline being taught.

- Demonstrating how the use of Moodle may have time-saving benefits may also increase academics' interest and commitment to Moodle. It would also be constructive to work with academics to understand their pedagogical approach to teaching and thus ensure that any technology introduced actually enhances their students' learning experience and/or their own teaching experience.

- Policy makers should seek to strengthen relationships and encourage collaboration between those in roles focused specifically on promoting learning technologies and those working to develop and improve academic practice, with a view to ensuring that both teams embed appropriate and effective technology use in the teaching and learning support they deliver to academics.

- Tactfully approaching academics with relatively low confidence in their Moodle competencies and offering customised support can improve the uptake. Encouraging reflection on the best use of Moodle to support learning objectives and outcomes can improve its effectiveness.

\section{References}

Bell, F. 2011. 'Connectivism: Its place in theory-informed research and innovation in technologyenabled learning.' The International Review of Research in Open and Distance Learning, 12(3). Available at: http://www.irrodl.org/index.php/irrodl/article/view/902/1664 (Accessed: 22 May 2014).

Blin, F. and Munro, M. 2008. 'Why hasn't technology disrupted academics' teaching practices? Understanding resistance to change through the lens of activity theory.' Computers \& Education, 50, 475-490.

Brenton, S. 2009. 'E-Learning - an introduction.' In: H. Fry, S. Ketteridge, \& S. Marshall, eds. $A$ handbook for teaching and learning in higher education 525. London: Routledge. 
Browne, T., Jenkins, M. and Walker, R. 2006. 'A Longitudinal Perspective regarding the use of VLEs by Higher Education institutions in the United Kingdom.' Interactive Learning Environments, 14(2). Available at: https://eric.exeter.ac.uk/repository/bitstream/handle/10036/13333/vle-surveylongitudinal-revision2.pdf?sequence=2 (Accessed: 22 July 2011).

Bush, M. and Mott, J. 2009. The Transformation of Learning with Technology: 'Learner-Centricity, Content and Tool Malleability, and Network Effects'. Educational Technology, 49(2), pp.3-20.

Denscombe, M., 2007. The good research guide for small-scale social research projects 3rd edition. Maidenhead, Berkshire: McGraw Hill Open University Press. Available at: http://valsciedu.weebly.com/uploads/2/7/9/1/2791482/the_good_research_guide.pdf (Accessed 25 June 2011).

Department for Continuing Education, University of Oxford, 2010. 'Study of UK Online Learning.' Higher Education Funding Council for England. Available at: http://www.hefce.ac.uk/pubs/rdreports/2010/rd17_10/rd17_10.pdf (Accessed 1 August 2011).

Department for Education and Skills, 2003. 'The future of higher education.' Department for Education and Skills. Available at:

http://www.dius.gov.uk/assets/biscore/corporate/migratedd/publications/f/future_of_he.pdf (Accessed: 3 August 2010).

Ellis, C. 2011. 'Grademark: showing how we use GradeMark as part of assessment management.' Available at: http://prezi.com/tcp_bjdgmlvu/grademark/ (Accessed: 3 August 2011).

Ellis, R., Steed, A. and Applebee, A. 2006. 'Teacher conceptions of blended learning, blended teaching and associations with approaches to design.' Australasian Journal of Educational Technology, 22(3), 312-335.

Fry, N. and Love, N. 2011. 'Business lecturers' perceptions and interactions with the virtual learning environment.' International Journal of Management Education, 9(4), 51-56.

Glatthorn, A. 1998. Writing the winning dissertation: a step-by-step guide illustrated. California: Corwin Press. Available at:

http://books.google.co.uk/books?id=uKGBQgAACAAJ\&dq=writing+the+winning+thesis+or+dissertat ion\&hl=en\&ei=4CYBTuasAor2sga-

ILDBDQ\&sa=X\&oi=book_result\&ct=result\&resnum=3\&ved=0CEEQ6AEwAg (Accessed: 21 June 2011).

Hanson, J. 2003. 'Encouraging Lecturers to Engage with New Technologies in Learning and Teaching in a Vocational University: The Role of Recognition and Reward.' Higher Education Management and Policy, 15(3), 153-170.

Hase, S. and Kenyon, C. 2001. 'From Andragogy to Heutagogy.' Available at: http://www.psy.gla.ac.uk/ steve/pr/Heutagogy.html (Accessed: 22 May 2014).

Heaton-Shrestha, C. et al. 2005. 'Introducing a VLE into campus-based undergraduate teaching: Staff perspectives on its impact on teaching.' International Journal of Educational Research, 43(6), 370-386. 
HEFCE 2001. Strategies for learning and teaching in higher education: a guide to good practice. UK: Higher Education Funding Council for England. Available at:

http://www.hefce.ac.uk/pubs/hefce/2001/01_37/01_37.pdf (Accessed: 29 July 2011).

HEFCE, Joint Information Systems Committee \& Higher Education Academy 2005. HEFCE strategy for e-learning, Higher Education Funding Council for England. Available at:

http://www.hefce.ac.uk/pubs/hefce/2005/05_12/05_12.pdf (Accessed: 3 August 2010).

Jenkins, M., Browne, T. and Armitage, S. 2001. Management and implementation of Virtual Learning Environments: a UCISA funded survey, UCISA. Available at:

http://www.ucisa.ac.uk/groups/ssg/ /media/groups/tlig/vle_surveys/VLEsurvey\%20pdf.ashx (Accessed: 22 July 2011).

Laurilliard, D. 2010. 'E-Learning in higher education.' In: Changing Higher Education.

RoutledgeFalmer. Available at:

https://www.adelaide.edu.au/clpd/resources/seminars/2006/harness_elearning/E-

Learning_in_Higher_Education.doc (Accessed: 7 April 2010).

Mingers, J. 2001. 'Combining IS Research Methods: towards a Pluralist Methodology.' Information Systems Research, 12(3), 240-259.

National Union of Students, 2010. Student perspectives on technology-demand, perceptions and training needs, Higher Education Funding Council for England. Available at:

http://www.hefce.ac.uk/pubs/rdreports/2010/rd18_10/rd18_10.pdf (Accessed: 1 August 2011).

Oliver, M. and Trigwell, K. 2005. 'Can 'Blended Learning' be redeemed?' E-Learning, 2(1), 17-26.

Schneckenberg, D., Ehlers, U. and Adelsberger, H. 2010. 'Web 2.0 and competence-oriented design of learning-Potentials and implications for higher education.' British Journal of Educational Technology - Wiley InterScience, 1-16.

Skelly, B. 2009. 'Age is no barrier to technology use.' The Post.IE - The Sunday Business Post Online. Available at: http://www.thepost.ie/archives/2009/0405/age-is-no-barrier-to-technology-use40767.html (Accessed: 21 August 2011).

Smith, J. 2005. 'From flowers to palms: 40 years of policy for online learning.' $A L T-J$, Research in Learning Technology, 13(2), 93-108.

Turcan, M. 2010. Expectancy theory as a predictor of faculty motivation to use a course management system. Doctor of Education. USA: Clemson University. Available at:

http://etd.lib.clemson.edu/documents/1285784347/Turcan_clemson_0050D_10802.pdf (Accessed: 18 July 2011).

Weller, M. 2006. 'VLE 2.0 and future directions in learning environments.' In: A. Voerman \& J. Dalziel, eds. Proceedings of the First International LAMSConference 2006: Designing the Future of Learning. LAMS Conference 2006: Designing the Future of Learning. Sydney, Australia: LAMS Foundation, 99-106. Available at: http://lamsfoundation.org/lams2006/pdfs/Weller_Lams06.pdf (Accessed: 17 August 2011). 


\section{Articles}

Willingham, D. 2002. 'Ask the Cognitive Scientist - Inflexible Knowledge: The First Step to Expertise.' American Federation of Teachers (AFT) - American Educator. Available at: http://www.aft.org/newspubs/periodicals/ae/winter2002/willingham.cfm (Accessed: 30 August 2010).

Zellweger Moser, F. 2007. 'Faculty adoption of educational technology: educational technology support plays a critical role in helping faculty add technology to their teaching.' Educause Quarterly, (1), 66-69.

Zemsky, R. and Massy, F. 2004. Thwarted innovation what happened to e-learning and why, Pennsylvania, USA: The Learning Alliance at the University of Pennsylvania. Available at: http://www.irhe.upenn.edu/Docs/Jun2004/Thwartedlnnovation.pdf (Accessed: 29 July 2011). 